\title{
Correction to: New examples of rational Gushel-Mukai fourfolds
}

\author{
Michael Hoff ${ }^{1} \cdot$ Giovanni Staglianò ${ }^{2}$
}

Published online: 21 June 2021

(c) Springer-Verlag GmbH Germany, part of Springer Nature 2021

\section{Correction to: Mathematische Zeitschrift (2020) 296:1585-1591 https://doi.org/10.1007/s00209-020-02498-5}

The article "New examples of rational Gushel-Mukai fourfolds", written by Michael Hoff and Giovanni Staglianò, was originally published Online First without Open Access. After publication in volume 296, issue 3-4, page 1585-1591 the author decided to opt for Open Choice and to make the article an Open Access publication. Therefore, the copyright of the article has been changed to (C) The Author(s) 2021 and the article is forthwith distributed under the terms of the Creative Commons Attribution 4.0 International License, which permits use, sharing, adaptation, distribution and reproduction in any medium or format, as long as you give appropriate credit to the original author(s) and the source, provide a link to the Creative Commons licence, and indicate if changes were made. The images or other third party material in this article are included in the article's Creative Commons licence, unless indicated otherwise in a credit line to the material. If material is not included in the article's Creative Commons licence and your intended use is not permitted by statutory regulation or exceeds the permitted use, you will need to obtain permission directly from the copyright holder. To view a copy of this licence, visit http://creativecommons.org/licen ses/by/4.0/.

The original article has been corrected.

Publisher's Note Springer Nature remains neutral with regard to jurisdictional claims in published maps and institutional affiliations.

The original article can be found online at https://doi.org/10.1007/s00209-020-02498-5.

Michael Hoff

hahn@math.uni-sb.de

Giovanni Staglianò

giovannistagliano@gmail.com

1 Universität des Saarlandes, Campus E2 4, 66123 Saarbrücken, Germany

2 Dipartimento di Matematica e Informatica, Università degli Studi di Catania, Viale A. Doria 5, 95125 Catania, Italy 